\title{
Eating and sociodemographic data of adults with type 1 Diabetes mellitus during COVID-19's social distancing
}

\author{
Alimentação e dados sociodemográficos de adultos com Diabetes mellitus tipo 1 durante o \\ distanciamento social da COVID-19 \\ Dieta y datos sociodemográficos de adultos con Diabetes mellitus tipo 1 durante el \\ distanciamiento social por COVID-19
}

Received: 01/17/2022 | Reviewed: 01/27/2022 | Accept: 02/03/2022 | Published: 02/05/2022

\author{
Jullyana Vago de Vilhena \\ ORCID: https://orcid.org/0000-0002-4870-7510 \\ Federal University of Pará, Brazil \\ E-mail: jullyanavilhena@gmail.com \\ Heloisy Andrea da Costa Brasil \\ ORCID: https://orcid.org/0000-0003-3657-1190 \\ Federal University of Pará, Brazil \\ E-mail: heloisybrasil@gmail.com \\ Jeane Lorena Dias Kikuchi \\ ORCID: https://orcid.org/0000-0002-8478-4740 \\ Federal University of Pará, Brazil \\ E-mail: nutri.jeanedias@yahoo.com \\ Manuela Maria de Lima Carvalhal \\ ORCID: https://orcid.org/0000-0003-1397-0471 \\ Federal University of Pará, Brazil \\ E-mail: manuela.carvalhall@gmail.com \\ Daniela Lopes Gomes \\ ORCID: https://orcid.org/0000-0002-0092-3396 \\ Federal University of Pará, Brazil \\ E-mail: danielagomes@ufpa.br
}

\begin{abstract}
Objective: Evaluate the association between eating habits and sociodemographic factors in adults with Type 1 Diabetes Mellitus (T1DM) during COVID-19's social distancing. Design: Transversal, descriptive and analytical study carried out in July 2020, using a form on the platform Google Forms ${ }^{\circledR}$. Sociodemographic data, information on social distancing and food choices were collected. For statistical analysis it was performed the Chi-Square Test, considering $\mathrm{p}<0.05$. Results: There was an association between social distancing and being female $(\mathrm{p}=0.014)$, living with individuals with diabetes $(\mathrm{p}=0.037)$ and having income maintained during the pandemic $(\mathrm{p}=0.032)$. Being female was associated with increased consumption of snacks $(\mathrm{p}=0.003)$ and sweets $(\mathrm{p}=0.016)$. Being between 18 and 24 years old was associated with changing food consumption $(\mathrm{p}=0.001)$, increasing consumption $(\mathrm{p}=0.001)$, especially snacks $(\mathrm{p}=0.005)$. Being over 45 years old was associated with maintaining the eating pattern $(\mathrm{p}=0.001)$. Having income maintained or increased was associated with maintaining the eating pattern $(\mathrm{p}=0.042)$. Conclusion: Age, gender and income can influence the eating habits of adults with T1DM during social distancing, which alerts to the need to maintain nutritional assistance in order to ensure a healthy eating pattern, as well as to have minimum income guarantee programs to ensure access to good quality food.
\end{abstract}

Keywords: COVID-19; Social isolation; Type 1 diabetes mellitus; Socioeconomic factors; Eating habits.

\section{Resumo}

Objetivo: Avaliar a associação entre hábitos alimentares e fatores sociodemográficos de adultos com Diabetes Mellitus tipo 1 (DM1) durante o distanciamento social da COVID-19. Métodos: Estudo transversal, descritivo e analítico, realizado em julho de 2020, por meio de formulário na plataforma Formulários Google®. Foram coletados dados sociodemográficos, informações sobre o distanciamento social e escolhas alimentares. Para análise estatística, foi realizado o Teste Qui-quadrado, considerando $\mathrm{p}<0,05$. Resultados: Observou-se associação entre realizar o distanciamento social e ser do sexo feminino $(\mathrm{p}=0,014)$, residir com indivíduos com diabetes $(\mathrm{p}=0,037)$ e ter a renda mantida durante a pandemia ( $\mathrm{p}=0,032)$. Ser do sexo feminino foi associado a aumentar o consumo de petiscos $(\mathrm{p}=0,003)$ e de doces $(p=0,016)$. Ter idade entre 18 e 24 anos estava associado a mudar o consumo alimentar $(p=0,001)$, a aumentar o consumo $(p=0,001)$, especialmente de petiscos $(p=0,005)$. Ter idade acima de 45 anos foi associado a manter o padrão 
alimentar nesse período $(\mathrm{p}=0,001)$. Ter a renda mantida ou aumentada durante a pandemia estava associado a manter o padrão alimentar ( $\mathrm{p}=0,042)$. Conclusão: Faixa etária, sexo e renda podem influenciar nos hábitos alimentares de adultos com DM1 durante o distanciamento social, o que alerta para a necessidade de manter a assistência nutricional nesse período a fim de garantir padrão alimentar saudável, bem como ter programas de garantia de renda mínima para assegurar o acesso a uma alimentação de boa qualidade.

Palavras-chave: COVID-19; Isolamento social; Diabetes mellitus tipo 1; Fatores socioeconômicos; Hábitos alimentares.

\section{Resumen}

Objetivo: Evaluar la asociación entre hábitos alimentarios y factores sociodemográficos en adultos con Diabetes Mellitus tipo 1 (DM1) durante el distanciamiento social por COVID-19. Diseño: Estudio transversal, descriptivo y analítico realizado en julio de 2020, mediante formulario en la plataforma Google Forms®. Se recopilaron datos sociodemográficos, información sobre distanciamiento social y elección de alimentos. Para el análisis estadístico se realizó la Prueba Chi-Cuadrado, considerando $\mathrm{p}<0,05$. Resultados: Hubo asociación entre el distanciamiento social y ser mujer ( $\mathrm{p}=0,014)$, vivir con personas con diabetes $(\mathrm{p}=0,037)$ y mantener ingresos durante la pandemia $(\mathrm{p}=0,032)$. Ser mujer se asoció con mayor consumo de snacks $(\mathrm{p}=0,003)$ y dulces $(\mathrm{p}=0,016)$. Tener entre 18 y 24 años se asoció con cambiar el consumo de alimentos $(\mathrm{p}=0,001)$, aumentar el consumo $(\mathrm{p}=0,001)$, especialmente snacks $(\mathrm{p}=0,005)$. Tener más de 45 años se asoció con el mantenimiento del patrón alimentario $(\mathrm{p}=0,001)$. Tener ingresos mantenidos o aumentados se asoció con el mantenimiento del patrón alimentario ( $\mathrm{p}=0,042)$. Conclusión: La edad, el género y los ingresos pueden influir en los hábitos alimentarios de los adultos con DM1 durante el distanciamiento social, lo que alerta sobre la necesidad de mantener la asistencia nutricional para asegurar un patrón de alimentación saludable, así como contar con programas de garantía de ingresos mínimos para asegurar el acceso a alimentos de buena calidad.

Palabras clave: COVID-19; Aislamiento social; Diabetes mellitus tipo 1; Factores socioeconómicos; Hábitos alimenticios.

\section{Introduction}

In 2020, after the World Health Organization declared the Coronavirus Disease 2019 (COVID-19) pandemic, social distancing was widely recommended, in order to control the spread of the Coronavirus and also protect the people most vulnerable to the disease's complications (Bedford \& Enria, 2020).

Individuals with diabetes are in the risk group for COVID-19, probably associated with chronic complications and of the lack of glycemic control (Gentile, et al., 2020). In the study by Holmann et al. (2020) it was observed that people with glycated hemoglobin (HbA1c) values above 10\% had a higher risk of a worse prognosis and death by COVID-19, both for patients with Type 1 diabetes mellitus (T1DM) and Type 2 (T2DM).

There is a significant impact of food on improving glycemic control and to preventing the early appearance of complications (Brazilian Diabetes Society [BDS], 2019). The study by Verma et al. (2020) demonstrated that the pandemic context can negatively affect the glycemic control of patients with T1DM, one of the causes being poor adherence to the diet.

In the period prior to the pandemic, studies discuss the importance of understanding the sociodemographic conjuncture to guide clinical conduct. According to Andrade et al. (2017), sociodemographic factors play an important role in the adherence to treatment of people with T1DM, with low glycemic control of these patients being common in Brazil, associated with low education and the perception of low adherence to diet and insulin therapy. Furthermore, Mendoza et al. (2018) concluded in their study that low and medium levels of food insecurity in people with T1DM are associated with higher levels of HbA1c. Marsola et al. (2020), when evaluating the reason for food choices and how socioeconomic characteristics and risk perception of chronic diseases affect them, observed that socioeconomic factors, such as income and education, strongly affect food choices.

Thus, despite a wide discussion about the importance of glycemic control in people with T1DM in COVID-19 pandemic, there is still a scarcity of studies that evaluated food choices and sociodemographic aspects by this public during the pandemic of COVID-19. Therefore, this study aims to assess the association between eating habits and sociodemographic factors in the context of social distancing in people with T1DM. 


\section{Methodology}

\subsection{Study type and participants}

Transversal, descriptive and analytical study carried out in July 2020. Transversal studies look forward to investigate variables in only one moment and they also allow the investigator to observe the variables without follow-ups and interventions in the sample. In addition, descriptive studies are characterized by describing in details the variables analyzed and analytical studies aim to analyze relations between the variables (Zangirolami-Raimundo et al., 2018). The call for participants took place through the internet in social networks of a research and extension project linked to a public university and in several other social networks that approach the T1DM theme (Facebook ${ }^{\circledR}$, Instagram ${ }^{\circledR}$ and WhatsApp $\left.{ }^{\circledR}\right)$.

Individuals aged 18 years old or over, diagnosed with T1DM and who agreed to participate in the online survey were included, selecting the option "I read the Informed Consent Form (ICF) and accept to participate in the survey" available at the beginning of the form. Then, the participants had to select which condition they fit, among the options: being an adult and having a diagnosis of T1DM; not having diabetes; have other types of diabetes; being a child or adolescent with T1DM; being a caregiver of a person with T1DM. If the selection did not correspond to the audience of adults with T1DM, the survey was automatically closed. Therefore, people who marked any alternative other than the inclusion criteria, people under 18 years of age, those who did not complete the form filling out or who did not agree with the ICF were excluded from the study.

\subsection{Data collection}

An online form was created on the Google Forms ${ }^{\circledR}$ platform, in the opinion survey format, in accordance with Resolution 510 of 2016, of the National Health Council (Brazil, 2016). The following information was collected:

- Sociodemographic data: sex, age, housing region (state, city), level of education, number of people with diabetes at home.

- Financial status: family income and receiving emergency aid.

- Eating during quarantine in relation to pre-pandemic pattern over a 30-day period: change in eating (has changed a lot; changed a little; or did not change); increase in food consumption (increased a lot; increased a little; remains the same; or decreased); number of daily meals (less than five meals; or greater than or equal to five meals); fruit consumption (adequate, for the consumption of two to three servings daily; and inadequate, for the consumption of less than two servings or greater than three servings daily); consumption of vegetables (adequate, when consumption was greater than or equal to two daily servings; and inadequate, when consumption was less than two daily servings); consumption of snacks, considering: packaged snacks, microwave popcorn, stuffed biscuits, biscuits or salty biscuits (more than before; equal to or less than before); consumption of ultra-processed foods, considering: ready-to-eat frozen foods such as nuggets, cheese bread, pizza or pasta (more than before; equal to or less than before); consumption of industrialized beverages (more than before; equal to or less than before); consumption of sweets (much more than before; a little more than before; the same as before; or decreased); and delivery orders (do not order or order less; order the same; or more than before).

- Social distancing: practiced total social distancing (was not going out for any activity); partial (going out only to buy food and/or medicine); did not practice social distancing, as they needed to go out to work; did not practice social distancing because did not agree with isolation; practiced social distancing for family reasons, despite not agreeing.

\subsection{Ethical aspects}

This research was approved by the Ethics and Research Committee (Opinion number: 4.147.663), according to the Helsinki Declaration. 
Informed consent was obtained from all individual participants included in the study.

\subsection{Statistical analysis}

For statistical analysis, the Statistical Package for Social Science software, version 21.0 was used (SPSS Inc., Chicago, IL, 2012). The Kolmogorov-Smirnov normality test was applied to verify the sample distribution. For descriptive analysis, measures of central tendency and dispersion were calculated. For analytical statistics, the social distancing variable had its categories grouped in order to classify into "yes", I was doing it, and "no", regardless of the reason. Pearson's Chi-Square test was performed with adjusted residual analysis (statistical significance $\mathrm{p}<0.05$ ).

\section{Results and Discussion}

472 people were evaluated with a mean age of $30.24 \pm 9.74$ years old, of which $86 \%$ were women $(p<0.000)$. Most lived in the Southeast region of Brazil (47\%; $\mathrm{p}<0.000)$. About $85 \%$ had adhered to social distancing $(\mathrm{p}<0.000)$. As for education, $26.9 \%$ had completed higher education ( $\mathrm{p}<0.000$ ). Regarding income, it was observed that $32.4 \%$ had an income between 3 to 5 minimum wages $(\mathrm{p}<0.000)$ and most continued in the same income range during the pandemic $(50.6 \% ; \mathrm{p}<0.000)$. Regarding the aid provided by the government, during the pandemic period, 39.2\% reported having received it ( $p<0.000$ ), in which $59.7 \%$ $(\mathrm{p}<0.000)$ stated that the benefit was used to pay basic bills (water, energy, gas, internet or telephone) -and $57.5 \%$ of these used the money to purchase food $(\mathrm{p}<0.000)$.

Regarding food during social distancing, 51.5\% reported that food consumption changed a little and $40.5 \%$ reported that food consumption increased a little $(\mathrm{p}<0.000)$. Regarding the purchase of food, $76.9 \%$ reported buying food in the same amount as before and $47.7 \%$ had 3 to 4 meals a day $(\mathrm{p}<0.000)$. As for the consumption of fruits and vegetables, most consumed 2 to 3 servings of each food group, with $42.6 \%$ referring to the consumption of fruits and $53.4 \%$ to vegetables ( $\mathrm{p}<0.000$ ). It was observed that most participants continued to consume ultra-processed foods $(38.1 \% ; \mathrm{p}<0.000)$, industrialized beverages $(45.3 \%$; $\mathrm{p}<0.000)$, snacks $(38.6 \% ; \mathrm{p}<0.000)$, sweets $(37.1 \% ; \mathrm{p}<0.000)$ and delivery orders $(26.9 \% ; \mathrm{p}<0.204)$ equally as in the period before the pandemic.

It was observed that being female $(\mathrm{p}=0.014)$, living with another person with diabetes in the same household $(\mathrm{p}=0.037)$ and having a family income maintained or increased during the pandemic $(\mathrm{p}=0.032)$ was associated with social distancing. In addition, having reduced income in this period was associated with not making social distancing $(\mathrm{p}=0.032)$ (Table 1$)$. 
Table 1 - Association between the practice of social distancing and the sociodemographics and economics data of adults with type 1 diabetes during covid-19's pandemic in brazil $(\mathrm{n}=472)$.

\begin{tabular}{|c|c|c|c|}
\hline & \multicolumn{2}{|c|}{ Social distancing } & \multirow[b]{2}{*}{ p-value* } \\
\hline & $\begin{array}{l}\text { Practiced } \\
\text { n }(\%)\end{array}$ & $\begin{array}{c}\text { Did not practiced } \\
\text { n }(\%)\end{array}$ & \\
\hline \multicolumn{4}{|l|}{ Sex } \\
\hline Female & $354(75)^{(+)}$ & $52(11)^{(-)}$ & \multirow[t]{2}{*}{0.014} \\
\hline Male & $50(10.6)^{(-)}$ & $16(3.4)^{(+)}$ & \\
\hline \multicolumn{4}{|l|}{ Housing region } \\
\hline Capital of state & $165(35)$ & $22(4.7)$ & \multirow{3}{*}{0.204} \\
\hline Metropolitan region & $94(19.9)$ & $14(3.0)$ & \\
\hline Countryside & $145(30.7)$ & $32(6.7)$ & \\
\hline \multicolumn{4}{|l|}{ People with diabetes at home } \\
\hline Yes & $62(13.1)^{(+)}$ & $4(0.8)^{(-)}$ & \multirow[t]{2}{*}{0.037} \\
\hline No & $342(72.5)^{(-)}$ & $64(13.6)^{(+)}$ & \\
\hline \multicolumn{4}{|l|}{ Family income } \\
\hline Remains the same or increased & $223(47.2)^{(+)}$ & $28(5.9)^{(-)}$ & \multirow[t]{2}{*}{0.032} \\
\hline Decreased & $181(38.3)^{(-)}$ & $40(8.5)^{(+)}$ & \\
\hline \multicolumn{4}{|l|}{ Received emergency aid } \\
\hline Received & $159(33.7)$ & $26(5.5)$ & \multirow[t]{2}{*}{0.861} \\
\hline Did not received & $245(51.9)$ & $42(8.9)$ & \\
\hline \multicolumn{4}{|l|}{ Level of education } \\
\hline Elementary school & $3(0.6)$ & $1(0.2)$ & \multirow{5}{*}{0.842} \\
\hline High school & $17(3.7)$ & $4(0.9)$ & \\
\hline Technical education & $54(11.7)$ & $11(2.4)$ & \\
\hline University education & $118(25.5)$ & $17(3.7)$ & \\
\hline Postgraduate & $203(43.9)$ & $34(7.4)$ & \\
\hline
\end{tabular}

(+) Positive significant association; (-) Negative significant association; *Pearson's chi-square test. Source: Authors (2020).

No association was found between adherence to social distancing and eating habits adopted during the pandemic (Table $2)$. 
Table 2 - Association between the practice of social distancing and eating habits of adults with type 1 diabetes mellitus ( $\mathrm{n}=472$ ).

\begin{tabular}{|c|c|c|c|}
\hline & \multicolumn{2}{|c|}{ Social distancing } & \multirow[b]{2}{*}{ p-value } \\
\hline & $\begin{array}{c}\text { Practiced } \\
\text { n }(\%)\end{array}$ & $\begin{array}{c}\text { Did not practiced } \\
\text { n }(\%)\end{array}$ & \\
\hline \multicolumn{4}{|l|}{ Change in eating } \\
\hline Changed a lot & $138(29.2)$ & $19(4.0)$ & \multirow{3}{*}{0.423} \\
\hline Changed a little & $203(43.0)$ & $40(8.5)$ & \\
\hline Did not change & $63(13.3)$ & $9(1.9)$ & \\
\hline \multicolumn{4}{|l|}{ Increase in food consumption } \\
\hline Increased a lot & $85(18.0)$ & $13(2.8)$ & \multirow{4}{*}{0.871} \\
\hline Increased a little & $161(34.1)$ & $30(6.4)$ & \\
\hline Remains the same & $91(19.3)$ & $13(2.8)$ & \\
\hline Decreased & $67(14.2)$ & $12(2.5)$ & \\
\hline \multicolumn{4}{|l|}{ Number of daily meals } \\
\hline$\geq 5$ meals & 207 (43.9) & $31(6.6)$ & \multirow[t]{2}{*}{0.389} \\
\hline Less than 5 meals & $197(41.7)$ & $37(7.8)$ & \\
\hline \multicolumn{4}{|l|}{ Fruit consumption } \\
\hline Adequate & $173(36.7)$ & $28(5.9)$ & \multirow[t]{2}{*}{0.800} \\
\hline Inadequate & $231(48.9)$ & $40(8.5)$ & \\
\hline \multicolumn{4}{|l|}{ Consumption of vegetables } \\
\hline Adequate & $211(44.7)$ & $41(8.7)$ & \multirow[t]{2}{*}{0.217} \\
\hline Inadequate & $193(40.9)$ & $27(5.7)$ & \\
\hline \multicolumn{4}{|l|}{ Consumption of snacks } \\
\hline More than before & $118(25.0)$ & $18(3.8)$ & \multirow[t]{2}{*}{0.645} \\
\hline Equal to or less than before & $286(60.6)$ & $50(10.6)$ & \\
\hline \multicolumn{4}{|l|}{ Consumption of ultra-processed food } \\
\hline More than before & $127(26.9)$ & $21(4.4)$ & \multirow[t]{2}{*}{0.928} \\
\hline Equal to or less than before & $277(58.7)$ & $47(10.0)$ & \\
\hline \multicolumn{4}{|c|}{ Consumption of industrialized beverages } \\
\hline More than before & $96(20.4)$ & $18(3.8)$ & \multirow[t]{2}{*}{0.503} \\
\hline Equal to or less than before & $308(65.3)$ & $50(10.6)$ & \\
\hline \multicolumn{4}{|l|}{ Consumption of sweets } \\
\hline Much more than before & $64(13.6)$ & $12(2.5)$ & \multirow{4}{*}{0.978} \\
\hline A little more than before & $128(27.1)$ & $22(4.7)$ & \\
\hline The same as before & $151(32.0)$ & $24(5.1)$ & \\
\hline Decreased & $61(12.9)$ & $10(2.1)$ & \\
\hline \multicolumn{4}{|l|}{ Delivery orders } \\
\hline Do not order or order less & $190(40.3)$ & $27(5.7)$ & \multirow[t]{2}{*}{0.262} \\
\hline Order the same or more than before & $214(45.3)$ & $41(8.7)$ & \\
\hline
\end{tabular}

(+) Positive significant association; (-) Negative significant association; *Pearson's chi-square test. Source: Authors (2020).

It was observed that being female was associated with having higher consumption of sweets consumption than before and being male, it was associated with maintaining the usual pattern $(\mathrm{p}=0.016)$. It was observed that having higher consumption of snacks than before was associated with the female sex and consumption equal to or less than before associated with the male $\operatorname{sex}(\mathrm{p}=0.003)($ Table 3$)$.

It was found that being between 18 and 24 years old was associated with changing one's food consumption. As well as being aged between 25 and 44 years old was associated with making few changes and not having changes in the eating pattern, and being aged 45 years or over was associated with not making alterations in eating $(\mathrm{p}=0.001)$. Furthermore, it was observed that being between 18 and 24 years old was associated with having increased food consumption. As well as being aged 25 to 44 years old was associated with having a little changes or decreased consumption, and being 45 years old or more was associated with having the same or decreased consumption $(\mathrm{p}=0.001)$. There was an association between being aged 18 to 24 years and 
consumption of snacks higher than before; as well as being aged from 25 to 44 years was associated with the consumption equal to or less than before $(\mathrm{p}=0.005)$ (Table 3$)$.

Table 3 - Association between sex, age and eating habits of adults with type 1 diabetes during social distancing ( $\mathrm{n}=472$ ).

\begin{tabular}{|c|c|c|c|c|c|c|c|}
\hline & \multicolumn{2}{|c|}{ Sex } & \multirow[b]{2}{*}{ p-value* } & \multicolumn{3}{|c|}{ Age (years old) } & \multirow[b]{2}{*}{ p-value* } \\
\hline & $\begin{array}{l}\text { Female } \\
\text { n }(\%)\end{array}$ & $\begin{array}{l}\text { Male } \\
\text { n }(\%)\end{array}$ & & $\begin{array}{c}18 \text { to } 24 \\
n(\%)\end{array}$ & $\begin{array}{c}25 \text { to } 44 \\
\text { n }(\%)\end{array}$ & $\begin{array}{c}\geq 45 \\
\mathrm{n}(\%)\end{array}$ & \\
\hline \multicolumn{8}{|l|}{ Change in eating } \\
\hline Changed a lot & $135(28.6)$ & $22(4.7)$ & \multirow{3}{*}{0.312} & $64(13.6)^{(+)}$ & $86(18.2)^{(-)}$ & $7(1.5)^{(-)}$ & \multirow{3}{*}{0.001} \\
\hline Changed a little & $213(45.1)$ & $30(6.4)$ & & $83(17.6)^{(+)}$ & $139(29.4)^{(+)}$ & $21(4.4)^{(-)}$ & \\
\hline Did not change & $58(12.3)$ & $14(3.0)$ & & $14(24.6)^{(-)}$ & $44(9.3)^{(+)}$ & $14(3.0)^{(+)}$ & \\
\hline \multicolumn{8}{|l|}{$\begin{array}{l}\text { Increase in food } \\
\text { consumption }\end{array}$} \\
\hline Increased a lot & $85(18.0)$ & $13(2.8)$ & \multirow{4}{*}{0.371} & $47(10.0)^{(+)}$ & $48(10.2)^{(-)}$ & $3(0.6)^{(-)}$ & \multirow{4}{*}{0.001} \\
\hline Increased a little & $168(35.6)$ & 23(4.9) & & $66(14.0)^{(+)}$ & $11(23.5)^{(+)}$ & $14(3.0)^{(-)}$ & \\
\hline Remains the same & $84(17.8)$ & $20(4.2)$ & & $23(4.9)^{(-)}$ & $63(13.3)^{(+)}$ & $18(3.8)^{(+)}$ & \\
\hline Decreased & 69(14.6) & $10(2.1)$ & & $25(5.3)^{(-)}$ & $47(10.0)^{(+)}$ & $7(1.5)^{(+)}$ & \\
\hline \multicolumn{8}{|l|}{ Number of daily meals } \\
\hline$\geq 5$ meals & $200(42.4)$ & $38(8.1)$ & \multirow{2}{*}{0.210} & $88(18.6)$ & $128(27.1)$ & $22(4.7)$ & \multirow{2}{*}{0.352} \\
\hline Less than 5 meals & 206(43.6) & $28(5.9)$ & & $73(15.5)$ & $141(29.9)$ & $20(4.2)$ & \\
\hline \multicolumn{8}{|l|}{ Fruit consumption } \\
\hline Adequate & $169(35.8)$ & $32(6.8)$ & \multirow{2}{*}{0.296} & $65(13.8)$ & $114(24.2)$ & $22(4.7)$ & \multirow{2}{*}{0.372} \\
\hline Inadequate & $237(50.2)$ & $34(7.2)$ & & $96(20.3)$ & $155(32.8)$ & $20(4.2)$ & \\
\hline \multicolumn{8}{|l|}{ Consumption of vegetables } \\
\hline Adequate & $214(45.3)$ & $38(8.1)$ & \multirow[b]{2}{*}{0.462} & $85(18.0)$ & $141(29.8)$ & $26(5.5)$ & \multirow[b]{2}{*}{0.509} \\
\hline Inadequate & $192(40.7)$ & $28(5.9)$ & & $76(16.1)$ & $128(27.1)$ & $16(3.4)$ & \\
\hline \multicolumn{8}{|l|}{ Consumption of snacks } \\
\hline More than before & $127(26.9)^{(+)}$ & $9(1.9)^{(-)}$ & \multirow[t]{2}{*}{0.003} & $61(12.9)^{(+)}$ & $67(14.2)^{(-)}$ & $8(1.7)^{(-)}$ & \multirow[t]{2}{*}{0.005} \\
\hline Equal to or less than before & $279(59.1)^{(-)}$ & $57(12.1)^{(+)}$ & & $100(21.2)^{(-)}$ & $202(42.8)^{(+)}$ & $34(7.2)^{(+)}$ & \\
\hline \multicolumn{8}{|l|}{$\begin{array}{l}\text { Consumption of ultra- } \\
\text { processed food }\end{array}$} \\
\hline More than before & $128(27.1)$ & $20(4.2)$ & \multirow[t]{2}{*}{0.842} & $53(11.2)$ & $82(17.4)$ & $13(2.8)$ & \multirow[t]{2}{*}{0.869} \\
\hline Equal to or less than before & 278(58.9) & $46(9.7)$ & & $108(22.9)$ & $187(39.6)$ & $29(6.1)$ & \\
\hline \multicolumn{8}{|l|}{$\begin{array}{l}\text { Consumption of } \\
\text { industrialized beverages }\end{array}$} \\
\hline More than before & $101(21.4)$ & $13(2.8)$ & \multirow{2}{*}{0.362} & $42(8.9)^{(+)}$ & $68(14.4)^{(+)}$ & $4(0.8)^{(-)}$ & 0066 \\
\hline Equal to or less than before & $305(64.6)$ & $53(11.2)$ & & $\underset{(-)}{119(25.2)}$ & $201(42.6)^{(-)}$ & $38(8.1)^{(+)}$ & 0.000 \\
\hline Consumption of sweets & & & & & & & \\
\hline Much more than before & $71(15.0)^{(+)}$ & $5(1.1)^{(-)}$ & & $25(5.3)$ & $47(10.0)$ & $4(0.8)$ & \\
\hline A little more than before & $135(28.6)^{(+)}$ & $15(3.2)^{(-)}$ & 0016 & $57(12.1)$ & $83(17.6)$ & $10(2.1)$ & 0288 \\
\hline The same as before & $141(29.9)^{(-)}$ & $34(7.2)^{(+)}$ & 0.010 & $55(11.7)$ & $97(20.6)$ & $23(4.9)$ & 0.288 \\
\hline Decreased & $59(12.5)^{(-)}$ & $12(2.5)^{(+)}$ & & $24(5.0)$ & $42(8.8)$ & $5(6.3)$ & \\
\hline Delivery orders & & & & & & & \\
\hline Do not order or order less & $190(40.3)$ & $27(5.7)$ & 0.373 & $70(14.8)$ & $122(25.8)$ & $25(5.3)$ & 0.169 \\
\hline $\begin{array}{l}\text { Order the same or more than } \\
\text { before }\end{array}$ & $216(45.8)$ & $39(8.3)$ & & $91(19.2)$ & $147(31.1)$ & $17(3.6)$ & \\
\hline
\end{tabular}

(+) Positive significant association; (-) Negative significant association; *Pearson's chi-square test. Source: Authors (2020).

It was observed that having the income maintained or increased was associated with maintaining the eating pattern during social distancing $(\mathrm{p}=0.042)$ and having had a decrease in income was associated with making changes in eating (Table 4). 
Table 4 - Association between income during the pandemic, education and eating habits of adults with type 1 diabetes during social distancing $(n=472)$.

\begin{tabular}{|c|c|c|c|c|c|c|}
\hline & \multicolumn{2}{|c|}{ Income in the pandemic } & \multirow[b]{2}{*}{ p-value* } & \multicolumn{2}{|c|}{ Level of education } & \multirow[b]{2}{*}{ p-value* } \\
\hline & $\begin{array}{c}\text { Remains the same or } \\
\text { increased } \\
\text { n }(\%) \\
\end{array}$ & $\begin{array}{c}\text { Decreased } \\
\text { n }(\%)\end{array}$ & & $\begin{array}{c}\text { Completed higher } \\
\text { education } \\
\text { n }(\%) \\
\end{array}$ & $\begin{array}{c}\text { No higher } \\
\text { education } \\
\text { n }(\%) \\
\end{array}$ & \\
\hline \multicolumn{7}{|l|}{ Change in eating } \\
\hline Changed a lot & $78(16.5)^{(-)}$ & $79(16.7)^{(+)}$ & \multirow{3}{*}{0.042} & $36(7.8)$ & $116(25.1)$ & \multirow{3}{*}{0.504} \\
\hline Changed a little & $125(26.5)^{(-)}$ & $118(25.0)^{(+)}$ & & $54(11.7)$ & $185(40.0)$ & \\
\hline Did not change & $48(10.2)^{(+)}$ & $24(5.1)^{(-)}$ & & $12(2.6)$ & $59(12.8)$ & \\
\hline \multicolumn{7}{|l|}{ Increase in food consumption } \\
\hline Increased a lot & $48(10.2)$ & $50(10.6)$ & \multirow{4}{*}{0.247} & $22(4.8)$ & $75(16.2)$ & \multirow{4}{*}{0.570} \\
\hline Increased a little & $95(20.1)$ & $96(20.3)$ & & $47(10.2)$ & $142(30.7)$ & \\
\hline Remains the same & $62(13.1)$ & $42(8.9)$ & & $18(3.9)$ & $79(17.1)$ & \\
\hline Decreased & $46(9.7)$ & $33(7.0)$ & & $15(3.2)$ & $64(13.9)$ & \\
\hline \multicolumn{7}{|l|}{ Number of daily meals } \\
\hline$\geq 5$ meals & $125(26.5)$ & $113(23.9)$ & \multirow{2}{*}{0.773} & $53(11.5)$ & 183(39.6) & \multirow{2}{*}{0.841} \\
\hline Less than 5 meals & $126(26.7)$ & $108(22.9)$ & & $49(10.6)$ & $177(38.3)$ & \\
\hline \multicolumn{7}{|l|}{ Fruit consumption } \\
\hline Adequate & $112(23.7)$ & 89(18.9) & \multirow{2}{*}{0.340} & $37(8.0)$ & $159(34.3)$ & \multirow{2}{*}{0.155} \\
\hline Inadequate & $139(29.4)$ & $132(28.0)$ & & $65(14.1)$ & $201(43.5)$ & \\
\hline \multicolumn{7}{|l|}{ Consumption of vegetables } \\
\hline Adequate & $134(28.4)$ & $118(25.0)$ & \multirow{2}{*}{0.999} & $50(10.8)$ & $198(42.90)$ & \multirow{2}{*}{0.285} \\
\hline Inadequate & $117(24.8)$ & $103(21.8)$ & & $52(11.3)$ & $162(35.1)$ & \\
\hline \multicolumn{7}{|l|}{ Consumption of snacks } \\
\hline More than before & $74(15.7)$ & $62(13.1)$ & \multirow{2}{*}{0.733} & $31(6.7)$ & 101(21.9) & \multirow{2}{*}{0.841} \\
\hline Equal to or less than before & $177(37.5)$ & $159(33.7)$ & & $71(15.4)$ & $259(56.1)$ & \\
\hline \multicolumn{7}{|l|}{$\begin{array}{l}\text { Consumption of ultra- } \\
\text { processed food }\end{array}$} \\
\hline More than before & $79(16.7)$ & $69(14.6)$ & \multirow{2}{*}{0.953} & $38(8.2)$ & $106(22.9)$ & \multirow{2}{*}{0.133} \\
\hline Equal to or less than before & $172(36.4)$ & $152(32.2)$ & & $64(13.9)$ & $254(55.0)$ & \\
\hline \multicolumn{7}{|l|}{ Consumption of } \\
\hline \multicolumn{7}{|l|}{ industrialized beverages } \\
\hline More than before & $54(11.4)$ & $60(12.7)$ & & $89(19.3)$ & $23(5.0)$ & \\
\hline Equal to or less than before & $197(41.7)$ & $161(34.1)$ & 0.153 & $271(58.7)$ & $79(17.1)$ & 0.651 \\
\hline Consumption of sweets & & & & & & \\
\hline Much more than before & $34(7.2)$ & $42(8.9)$ & & $15(3.2)$ & $59(12.8)$ & \\
\hline A little more than before & $73(15.5)$ & $77(16.3)$ & م 100 & 26(5.6) & $119(25.8)$ & 0366 \\
\hline The same as before & $102(21.6)$ & $73(15.5)$ & 0.100 & $45(9.7)$ & $128(27.7)$ & 0.360 \\
\hline Decreased & $42(8.9)$ & $29(6.1)$ & & $16(3.5)$ & $54(11.7)$ & \\
\hline Delivery orders & & & & & & \\
\hline Do not order or order less & $110(23.3)$ & $107(22.7)$ & 0.318 & $52(11.3)$ & $162(35.1)$ & 0.285 \\
\hline $\begin{array}{l}\text { Order the same or more than } \\
\text { before }\end{array}$ & 141(29.9) & $114(24.2)$ & 0.510 & $50(10.8)$ & 198(42.9) & 0.285 \\
\hline
\end{tabular}

(+) Positive significant association; (-) Negative significant association; *Pearson's chi-square test. Source: Authors (2020).

\section{Discussion}

In the present study, it was possible to evaluate the association between eating and sociodemographic factors of people with T1DM in the context of social distancing due to COVID-19 in Brazil. It was observed that being female was associated with performing social distancing, which corroborates the findings of Coriou et al. (2020), who in seeking to identify barriers and facilitators of adherence to social distancing, observed that women were more likely to avoid socialize in person and keep a safe distance when in public. Data from the Ministry of Health indicate that women, in general, express greater concerns and care for their health, and attend the health system more, seeking not only care for themselves, but also for family members, 
neighbors or friends (Brazil, 2011). Therefore, the hypothesis is suggested that due to this profile, they were taking the measures of social distancing more seriously when compared to men.

Living with another person with diabetes was associated with the practice of distancing. According to Gentile et al. (2020), COVID-19 mainly affects men in advanced age and with the presence of comorbidities such as DM. Besides, in China the mortality rate in people with DM was 7.3\%, being considered high (Wu \& McGoogan, 2020). Therefore, the hypothesis is suggested that this high mortality rate, in line with the characteristics of the most affected groups, are factors that generate fear and concern to individuals and that may explain the association with the greater practice of social distancing.

The equal or increased income was associated to practicing social distancing. As Afifi et al. (2020) discusses, the social conditions of individuals directly affect their ability to avoid the disease or diminish its consequences. These conditions are related to the level of financial resources, knowledge and power of individuals, and interfere or make impossible the recommended prevention strategies, such as hand washing, social distancing, orders to stay at home and isolation in case of infection. As well as Burnquist et al. (2020) stated that those most affected by COVID-19 are those workers whose families depend on income from daily activities, since family support depends on the service performed, and thus, it is difficult to practice social distancing without a source of income to ensure basic needs.

Associations were found between age and changes in food consumption. Ruiz-Roso et al. (2020) observed that older individuals with T2DM did not change consumption compared to younger ones, and it is argued that this may be due to the higher level of awareness regarding the consequences of inadequate eating habits in the metabolic control of DM. Moreover, when evaluating knowledge, attitudes and practices regarding COVID-19 in young adults with T1DM, Pal et al. (2020) mention that young people are in the transition between pediatric and adult care, which makes their engagement in health-related behaviors more unstable, besides being more likely to engage in behaviors that pose health risks.

It was observed that decreased income was associated with alterations in eating. In the study by Grabia et al. (2020), in which the majority of the sample was composed of individuals with T1DM, 21\% were unemployed and the rest were students, of whom $60 \%$ affirmed to have improved their eating habits, but, the authors did not evaluate the association between these variables. However, in deriving trajectories of eating alterations during isolation and associated risk factors in UK adults, Herle et al. (2021) found that people with lower incomes were less likely to eat more during social distancing, probably due to financial problems.

No studies were found with individuals with T1DM that made an association between age and increased food consumption, but when evaluating the eating habits and lifestyle changes of the Italian population during quarantine by COVID19, Di Renzo et al. (2020) observed that 34.4\% reported having more appetite during this period and people who had more appetite were younger. In the study by Grabia et al. (2020), the authors found that $65 \%$ of the participants started to eat more regularly during the pandemic, especially the main meals. When evaluating the effects of quarantine on people with T1DM and their caregivers, Tejera-Perez et al. (2021) identified that $40.4 \%$ of participants reported weight gain associated with increased food consumption. In addition, participating caregivers reported higher than normal glycemic control and insulin requirements. As identified by Grabia et al. (2020), 40\% of the participants had problems controlling their weight during social distancing, probably due to the increase in the number of daily meals.

Associations were found between being female and consuming more sweets. No studies were found to evaluate these associations in people with T1DM, however, in general, Mattioli et al. (2020) mention that in situations of chronic stress, such as the pandemic period, people seek and consume foods with greater energy density. When evaluating eating changes among Brazilians during the pandemic, Malta et al. (2020) observed that women increased the frequency of consumption of sweets. Thus, when evaluating Saudi women during the COVID-19 pandemic, Al-Musharaf et al. (2020) found that the consumption of 
sweet foods was one of the indicators of emotional eating and an adaptive mechanism for dealing with the negative emotions of the social distancing period.

No studies were found that evaluated the association of snack consumption with age and gender in people with T1DM, however, in the study by Ruiz-Roso et al. (2020), when evaluating people with T2DM, they observed that during the period of social distancing, women increased their consumption of snacks. Si Hassen et al. (2018), when evaluating socioeconomic factors associated with snacking consumption in adults, observed that women snacked more frequently during the week.

In the study by Grabia et al. (2020), more than $30 \%$ of individuals affirmed that they had increased the frequency of eating snacks between meals during social distancing. Nogueira Bezerra et al. (2018), when seeking to describe the eating habits of Brazilian people, observed that young adults have a lower frequency of consumption of healthy foods and a higher frequency of unhealthy foods when compared to middle-aged adults. Corroborating the results, the study by Malta et al. (2020) with Brazilian adults in the COVID-19 pandemic, young adults increased the frequency of consumption of unhealthy foods during the pandemic.

The present study had the limitations of not having assessed glycemic control, so there is no way to say whether eating changes caused positive or negative changes in this aspect. In addition, conducting an online survey may not reach individuals with T1DM who do not have access to the internet and/or electronic media. However, it was observed a scarcity of studies that explored eating changes and associated factors in people with T1DM during the COVID-19 pandemic, so this study allows us to contribute to the literature and highlight the need for further research addressing this topic, in order to generate a greater understanding of how the context of the pandemic influenced the eating habits of these individuals and other factors that may be associated.

\section{Conclusion}

In this study, it was observed the association between social isolation and being female, living with individuals with diabetes and having family income maintained during the COVID-19 pandemic. Furthermore, it was noted that being female was associated with increased consumption of snacks and sweets. Being between 18 and 24 years old was associated with increasing food consumption, especially snacks. Having income maintained or increased during the pandemic was associated with maintaining the eating pattern. It is important to highlight the need for maintenance of nutritional assistance by professionals during this period, in order to ensure a healthy eating pattern, as well as to implement government actions to continue the minimum income guarantee programs to ensure the population's access to good quality food.

Therefore, it is suggested new studies about the effects of the COVID-19 pandemic in the eating habits of people with T1DM, in order to observe the impacts of the changes and their relation sociodemographic factors, and if the adopted behaviors were sustained or modified in a long-term period. In addition, further studies are suggested to assess the association between eating habits and glycemic control during the COVID-19 pandemic.

\section{References}

Afifi, R. A., Novak, N., Gilbert, P. A., Pauly, B., Abdulrahim, S., Rashid, S. F., \& Ferrand, R. A. (2020). 'Most at risk'for COVID19? The imperative to expand the definition from biological to social factors for equity. Preventive medicine, 139, 106229. https://doi.org/10.1016/j.ypmed.2020.106229

Al-Musharaf, S. (2020). Prevalence and predictors of emotional eating among healthy young Saudi women during the COVID-19 pandemic. Nutrients, 12(10), 2923. https://doi.org/10.3390/nu12102923.

Andrade, C. S., Ribeiro, G. S., Santos, C. A. S. T., Neves, R. C. S., \& Moreira, E. D. (2017). Factors associated with high levels of glycated haemoglobin in patients with type 1 diabetes: a multicentre study in Brazil. BMJ open, 7(12), e018094. http://dx.doi.org/10.1136/bmjopen-2017-018094.

Bedford, J., Enria, D., Giesecke, J., Heymann, D. L., Ihekweazu, C., Kobinger, G., \& Oh, M. (2020). D., Sall AA, Schuchat A., Ungchusak K., Wieler LH. Lancet, 395, 1015. 
Bezerra, I. N., de Carvalho Gurgel, A. O., Barbosa, R. B., \& da Silva, G. B. (2018). Dietary behaviors among young and older adults in Brazil. The journal of nutrition, health \& aging, 22(5), 575-580. 10.1007/s12603-017-0978-0.

Brazilian Diabetes Society. (2019) Brazilian Diabetes Society Guidelines (2019-2020). (C. E. scientific, Org.).

Burnquist, H. L., Martins, M. M. V., Campoli, J. S., \& da Costa, C. C. (2020). Covid-19 e agroalimentos Recalibrando expectativas. Embrapa InstrumentaçãoArtigo em periódico indexado (ALICE).

Coroiu, A., Moran, C., Campbell, T., \& Geller, A. C. (2020). Barriers and facilitators of adherence to social distancing recommendations during COVID-19 among a large international sample of adults. PloS one, 15(10), e0239795. https://doi.org/10.1371/journal.pone.0239795

Di Renzo, L., Gualtieri, P., Pivari, F., Soldati, L., Attinà, A., Cinelli, G., \& De Lorenzo, A. (2020). Eating habits and lifestyle changes during COVID-19 lockdown: an Italian survey. Journal of translational medicine, 18, 1-15. https://doi.org/10.1186/s12967-020-02399-5

Gentile, S., Strollo, F., \& Ceriello, A. (2020). COVID-19 infection in Italian people with diabetes: Lessons learned for our future (an experience to be used). Diabetes research and clinical practice, 162. https://doi.org/10.1016/j.diabres.2020.108137

Grabia, M., Markiewicz-Żukowska, R., Puścion-Jakubik, A., Bielecka, J., Nowakowski, P., Gromkowska-Kępka, K., \& Socha, K. (2020). The nutritional and health effects of the COVID-19 pandemic on patients with diabetes mellitus. Nutrients, 12(10), 3013.. https://doi.org/10.3390/nu12103013

Hassen, W. S., Castetbon, K., Péneau, S., Tichit, C., Nechba, A., Lampuré, A., \& Méjean, C. (2018). Socio-economic and demographic factors associated with snacking behavior in a large sample of French adults. international journal of behavioral nutrition and physical activity, 15(1), 1-12. 10.1186/s12966-018-06557.

Herle, M., Smith, A. D., Bu, F., Steptoe, A., \& Fancourt, D. (2021). Trajectories of eating behavior during COVID-19 lockdown: Longitudinal analyses of 22,374 adults. Clinical Nutrition ESPEN, 42, 158-165. https://doi.org/10.1016/j.clnesp.2021.01.046

Holman, N., Knighton, P., Kar, P., O'Keefe, J., Curley, M., Weaver, A., \& Valabhji, J. (2020). Risk factors for COVID-19-related mortality in people with type 1 and type 2 diabetes in England: a population-based cohort study. The lancet Diabetes \& endocrinology, 8(10), 823-833. https://doi.org/10.1016/S2213$8587(20) 30271-0$

Marsola, C. D. M., Cunha, L. M., Carvalho-Ferreira, J. P. D., \& da Cunha, D. T. (2020). Factors underlying food choice motives in a Brazilian sample: The association with socioeconomic factors and risk perceptions about chronic diseases. Foods, 9(8), 1114. https://doi.org/10.3390/foods9081114

Mattioli, A. V., Sciomer, S., Cocchi, C., Maffei, S., \& Gallina, S. (2020). Quarantine during COVID-19 outbreak: Changes in diet and physical activity increase the risk of cardiovascular disease. Nutrition, Metabolism and Cardiovascular Diseases, 30(9), 1409-1417. https://doi.org/10.1016/j.numecd.2020.05.020

Malta, D. C., Szwarcwald, C. L., Barros, M. B. D. A., Gomes, C. S., Machado, Í. E., Souza, P. R. B. D., \& Gracie, R. (2020). The COVID-19 Pandemic and changes in adult Brazilian lifestyles: a cross-sectional study, 2020. Epidemiologia e Serviços de Saúde, 29. https://doi.org/10.1590/S1679-49742020000400026

Mendoza, J. A., Haaland, W., D'Agostino, R. B., Martini, L., Pihoker, C., Frongillo, E. A., \& Liese, A. D. (2018). Food insecurity is associated with high risk glycemic control and higher health care utilization among youth and young adults with type 1 diabetes. Diabetes research and clinical practice, $138,128-137$. https://doi.org/10.1016/j.diabres.2018.01.035

Ministery of Health (Brazil) (2011). National Politcy of Comprehensive Care for Women's Health: principles and guidelines. Brasília: Editora MS; 44 p. National Health Council (Brazil) (2016). Resolution $n^{\circ}$. 510, of April 7th 2016. Standards applicable to research in Humanities and Social Sciences. Official Gazette of the Union. 24 may 2016.

Pal, R., Yadav, U., Grover, S., Saboo, B., Verma, A., \& Bhadada, S. K. (2020). Knowledge, attitudes and practices towards COVID-19 among young adults with Type 1 Diabetes Mellitus amid the nationwide lockdown in India: A cross-sectional survey. Diabetes research and clinical practice, $166,108344$. https://doi.org/10.1016/j.diabres.2020.108344

Ruiz-Roso, M. B., Knott-Torcal, C., Matilla-Escalante, D. C., Garcimartín, A., Sampedro-Nuñez, M. A., Dávalos, A., \& Marazuela, M. (2020). COVID-19 lockdown and changes of the dietary pattern and physical activity habits in a cohort of patients with type 2 diabetes mellitus. Nutrients, 12 (8), 2327. https://doi.org/10.3390/nu12082327

Tejera-Perez, C., Moreno-Pérez, Ó., Rios, J., \& Reyes-García, R. (2021). People living with type 1 diabetes point of view in COVID-19 times (COVIDT1 study): Disease impact, health system pitfalls and lessons for the future. Diabetes Research and Clinical Practice, 171 , 108547. https://doi.org/10.1016/j.diabres.2020.108547

Verma, A., Rajput, R., Verma, S., Balania, V. K., \& Jangra, B. (2020). Impact of lockdown in COVID 19 on glycemic control in patients with type 1 Diabetes Mellitus. Diabetes \& Metabolic Syndrome: Clinical Research \& Reviews, 14(5), 1213-1216. https://doi.org/10.1016/j.dsx.2020.07.016

Wu, Z., \& McGoogan, J. M. (2020). Characteristics of and important lessons from the coronavirus disease 2019 (COVID-19) outbreak in China: summary of a report of 72314 cases from the Chinese Center for Disease Control and Prevention. Jama, 323(13), 1239-1242. 10.1001/jama.2020.2648.

Zangirolami-Raimundo, J., Echeimberg, J. D. O., \& Leone, C. (2018). Tópicos de metodologia de pesquisa: Estudos de corte transversal. J Hum Growth Dev, 28(3), 356-60. 